\title{
'I'm not a very good visionary': challenge and change in twenty-first century North American archival education
}

\author{
Alex H. Poole ${ }^{1}$ (D) . Ashley Todd-Diaz ${ }^{2}$ \\ Accepted: 3 February 2022 / Published online: 8 March 2022 \\ (C) The Author(s), under exclusive licence to Springer Nature B.V. 2022
}

\begin{abstract}
Since the founding of the National Archives (1934) and the Society of American Archivists (1936), archival scholars, educators, and practitioners have discussed and debated the challenges of and future directions for graduate archival education. This exploratory qualitative case study uses semistructured interviews with 33 tenuretrack and tenured faculty members from North American graduate archival programs to explore the most pressing issues facing archival education in the twentyfirst century. Showing both continuity and change, findings extend and enrich the literature regarding faculty, curriculum, interdisciplinarity and collaboration, DEI, technology, and sustainability.
\end{abstract}

Keywords Archival education - Archival pedagogy $\cdot$ Archival training $\cdot$ Archival educators

\section{Introduction}

Who an archivist is as well as what an archivist does has long remained an enigma. Glossing Crèvecoeur's Letters from an American Farmer, Society of American Archivists president Posner (1957) mused, "What, Then, Is the American Archivist, This New Man?" Posner's rumination pointed to a complementary question, that is, how should an archivist, however defined, be educated?

Expanding Posner's focus from the USA to North America, this exploratory qualitative case study unpacks the most pressing issues facing graduate archival educators and archival education more broadly. First, we review the literature. Second, we state our methodological approach. Third, we discuss findings, homing in on faculty, curriculum, interdisciplinarity and collaboration, diversity, equity, and inclusion

Alex H. Poole

ahp56@drexel.edu

1 Drexel University, Philadelphia, PA, USA

2 Towson University, Towson, MD, USA 
(DEI), digital technology, and sustainability. Fourth, our discussion addresses our findings' implications. Fifth, we offer conclusions and directions for future research.

Cox (2000a) lamented, "indicative of [archival studies's] youthfulness is the fact that we have done so little research about our own educational programs" (p. 375). Two decades later, his observation remains valid. This article addresses this knowledge gap.

\section{Literature review}

Archival educators, the curriculum, interdisciplinarity and collaboration, diversity, equity, and inclusion, digital technology, and sustainability—all represent nodes of scholarly debate in North American archival discourse.

\section{Archival educators}

Though archival educators remain understudied (Gilliland 2011), scholars discuss the need for full-time faculty, balancing teaching and research, and the faculty-practitioner relationship.

\section{The need for full-time tenure-track academic faculty}

Archival educators long included a mix of practitioners and scholars holding advanced degrees in library science or history, but rarely both (Freeman 1991; Geary 1979; Mason 1972; McCrank 1979). The mixed pedigree of archival educators stemmed from the nature of the field itself: "the administration of modern archives and manuscripts is neither an exclusively intellectual discipline, nor a craft, nor a trade, nor yet an art, but it shares elements of all of these" (Mason 1972, p. 207). It therefore demanded both intellectual and practical insights from variegated stakeholders.

Historically, scholars favored practical experience as a foundational qualification for archival instructors; moonlighting practitioners dominated the ranks of educators until the late 1980s (Burke 1976; Evans 1972; Jones 1968). Over time, however, an increasing number of scholars demanded more than just experience. Colson (1968) recommended that educators be scholars and critics as well as practitioners, Mason (1972) called for germane academic qualifications as well as training and experience, Warner (1972) found agreement among his survey respondents that the instructors needed an academic background in history and archival experience, and Geary (1979) claimed the ideal educator possessed both a Ph.D. in history and work experience. McCrank (1979) meanwhile insisted that the employment of practicing archivists as part-time faculty hindered theoretical research and thus ultimately curtailed professional progress. Only full-time, tenured or tenure-track archival faculty should direct archival education programs, he reasoned (McCrank 1980).

Like McCrank, Berner (1981) believed that moonlighting practitioners simply could not provide the best educational experience and Burke (1981) insisted that 
professional progress hinged on dedicated full-time faculty. Helmuth (1981), however, maintained that programs could not support such a faculty. Although Joyce (1988) noted that the number of archives faculty positions would never be large simply because enrollments would remain modest, Conway (1988) like Burke advocated for a "critical mass" (p. 261) of full-time faculty, a point recapitulated by Ericson (1993).

At the turn of the millennium, Cox et al. (2001a) celebrated the growing number of full-time tenure-track faculty in LIS programs; concordantly, programs offered ever more archives courses (Cox et al. 2001b). All the same, many programs depended still upon a sole educator, so their existence remained imperiled (Bastian and Yakel 2006; Cox et al. 2001a; Yakel 2004). In a far cry from fifteen years prior, Cox (2015) worried about the field's possible attrition.

\section{Balancing teaching and research}

Archival educators' educational and vocational background shifted over time.

In a reificatory but useful passage, Cox et al. (2001a) identified three generations of archival educators:

The first generation of archival educators possessed PhDs in history; the second generation slowly drifted toward LIS doctoral programs and wrote dissertations on archival topics with little or no archival faculty or curricular support. The third generation of archival doctoral candidates has the opportunity of studying with archival faculty, taking advantage of courses focused on archival issues, and participating in archival research projects (p. 237).

Full-time, tenure-track archives faculty members of the third generation, however, negotiated an increasingly challenging occupational landscape. On the one hand, teaching in professional schools such as LIS ostensibly demanded that educators foreground pragmatic training and skills acquisition, not least because of the ever-increasing cost of a degree coupled with an ever-tightening employment market (Cox 2009). On the other, tenure-track or tenured faculty faced a paradox: "If faculty members engage in building a body of scholarship, the very professions in which they supposedly equip new practitioners to work may chide them, and if they focus on teaching to prepare these practitioners, they may be shunned in their own schools for a lack of productivity" (Cox 2009). Despite his advocacy of full-time research faculty, Cox (2015) subsequently fretted over new Ph.Ds., a so-called fourth generation, lacking practical experience and thereby losing credibility with students qua aspiring practitioners.

\section{The Faculty/practitioner relationship}

Some literature addresses the faculty-practitioner relationship. Stielow (1993) branded professional jurisdictional skirmishes an inevitable accompaniment of growth. He offered a three-pronged critique of practitioners as educators. First, practitioner educators tended to teach what people currently did, marginalizing research 
and theoretical components. Second, practitioners tended not to delve into interdisciplinarity. Third, few practitioners occupied the technological vanguard or seemed motivated to join it.

A decade later, Cox (1994) also alluded to manifest shortcomings of practitionerled education. A practice-based approach oriented students only to a particular archival program's knowledge, he contended. He therefore eschewed training that centered on current practice, preferring education comprising methods and theory that funneled into practice.

North American programs set up their educational offerings pragmatically, namely basic training in appraisal and arrangement and description, according to Schaeffer (1994). This yielded "a profession of practitioners" who subscribed to the merits of mere clinical instruction (p. 22). Usually trained post-appointment, practitioners evinced reticence about the merits of education that failed to hinge on practical instruction. Similarly, they resisted ascribing professional status to individuals with only academic credentials. Even as he warned against educators' sundering their connection with practice, Schaeffer (1994) conceded that an unduly practiceoriented education reflected a jaundiced approach.

Harkening to Stielow (1993) and Cox (1994), Cook (2000) ascertained anti-intellectualism in the profession. He saw "misunderstandings of discipline versus profession; theory versus practice; education versus training; and 'new' recordkeeping, electronic records models versus 'traditional' cultural, heritage, and historical orientations" (p. 380).

Cox (2006), too, called attention to the differing cultures occupied by faculty and practitioners. He characterized the former as mostly knowledge producers, the latter as mostly knowledge consumers. Echoing Cox, Gilliland (2011) noted that educators' priorities failed to align with those of practitioners. The former remained accountable via research, teaching, and service to their own institutions. Cox (2015) reiterated his earlier position: faculty's accountability to their university, not to the profession, rendered educator/practitioner tension explicable if not inevitable. Although the two groups dealt with a drastically different reward system, Cox maintained that a good working relationship remained feasible nonetheless. Eastwood (2017) likewise saw an inherent risk of estrangement between educators and practitioners, he asserted nonetheless that both camps' perspectives could limn common issues concerning the philosophy, scope, and content of graduate education.

\section{Curriculum}

Scholars also touch upon the challenges of content coverage and the opportunities and drawbacks of online teaching.

\section{Content coverage}

Bower (1977) found that of 23 archives programs, educators' primary self-criticism was of their courses were too brief or too circumscribed in scope. Cox (1993) suggested that even seven courses fell short of imparting the full range of archival 
knowledge, and Duranti (1993) and Tibbo (1997) also thought curriculum brevity the most formidable challenge for educators. This surfeit of content overwhelmed the master's level curriculum, especially as educators perforce spent more class time on computing technology, information management, and recordkeeping; historical and cultural topics suffered as a result (Cook 2000).

Bastian (2006) like Cook found a balancing act between traditional and new topics (e.g., information management) tricky. Tibbo (2006) reiterated her concern over the brevity of the Master's curriculum. While SAA's Guidelines for a Program in Archival Studies (2002) prescribed an extensive cluster of knowledge areas a program should cover, it ignored this salient constraint. Additionally, Tibbo (2006) noted that the proposed half-measure, viz., integrating archival content into other courses, had not occurred. She ascribed this not only to a lack of motivation on the part of educators, but also to a lack of team taught courses.

\section{Online teaching}

Few scholars discuss online education. Boles (1996) argued that distance education facilitated equal access to archival education. Learning could occur anywhere and anytime through distance-later online-education. For example, Franks (2016, 2012) and Franks and Oliver (2012) found success developing communities of practice through online experiential learning.

Conversely, online education potentially engendered isolation, and thus a lack of belonging and immediacy that could be but partly addressed by technology (Franks 2012). More caustic, Cox (2006) characterized distance education as mere content "packaged in digestible bites," suited only to technical training, not education (p. 250). Distance education abrogated potential faculty-student collaboration and to Cox remained just a revenue generator for the corporate university. Online education further encouraged the overproduction of graduates despite a clotted employment market (Cox 2015). Apropos of online education, Tibbo (2015) chimed in that online students likely struggled more than resident students to secure rewarding field experiences.

Despite his disapproval, Cox (2015) predicted that all archival education save doctoral studies would migrate online as soon as universities tamed requisite technical challenges.

\section{Interdisciplinarity and collaboration}

Archival studies borrow from discipline and fields such as history, library and information science, the social sciences and humanities more broadly, education, management, and public relations (Eastwood 2017; Freeman 1991; McCrank 1979; Schellenberg 1968; Tibbo 1997). Eastwood (1988) contends that archivists "are children and servants of many disciplines, and that is their glory, not their intellectual disability" (Eastwood 1988, p. 238). Archival studies similarly resulted from "many fields, schisms, and realignments" (Cox 2012, p. 42). 
Many scholars debate the best university host for archival education, a debate that concerns the intellectual wellspring of professional education. Rather ironically, there seemed more scholarly attention devoted to the location of programs than to their content (Davis 1989). Scholars argued for placement in or collaboration with history (Bauer 1955; Bemis 1939; Brooks 1951; Buck 1941; Jones 1968; McCrank 1980; Newsome 1939; Posner 1967, 1941), public history (Cox and Larsen 2008; Kovan 1988; McCrank 1985; Smith 1994; Walters 1991), and LIS (Boles 1990; Cox 2000a; Cox et al. 2001b; Eastwood 1988; Evans 1972, 1977; Geary 1979; Peace and Chudacoff 1979; Schellenberg 1968; Trever 1948; Walters 1991). But for nearly four decades, scholars have also expressed doubts about the debate's utility (Burke 1983; Cox 1990a; McCrank 1985; Miller 2000; Tibbo 1997).

A complementary discussion concentrated on the integration of archives with host LIS programs. Peace and Chudacoff (1979), for example, contended that LIS courses covered all SAA's foundational 1977 educational guidelines in courses such as cataloging, administration, and reference.

According to Ericson (1993), moreover, LIS educators thought LIS and archives of the same intellectual family. But even if skills such as reference and collection development were essential to all information specialists, existing LIS reference courses included scant archival content. Ericson felt skeptical about a successful grafting of archival topics onto LIS courses.

Host program concerns aside, scholars debated the interdisciplinary nature of the field. Berner (1981) emphasized the importance of interdisciplinary collaboration to construct an optimal archival curriculum, a point bolstered by Tibbo (1997). Subsequent scholarship fastened on the potential of information technology to effect convergence among disciplines-for better or worse. Stielow (1993) saw information management possibly absorbing archival studies. Similarly, Nesmith (1996) wondered whether information technology would lead not only to convergence, but to the archival field's potential colonization by other information professions. Like Nesmith, Yakel (2004) warned against undue convergence for fear of watering down the archival curriculum. At the same time, she predicted that to deal professionally with convergence, students would need to augment their technical, information management, user interaction, and collection development skills to embrace new content types and formats, and new institutions.

Like Yakel, Nesmith, and Stielow, Cox (2012) saw digital technology's apparent omnipresence pointing toward convergence among libraries, archives, and museums (LAMs). He soon (2015) revisited this assertion, speculating on the likelihood of a final LAM convergence, potentially under the auspices of Big Data.

\section{Diversity, equity, and inclusion (DEI)}

Both archival educators and the archival profession struggle to promote DEI, particularly in terms of race, ethnicity, and gender (Poole 2018, 2017a, 2017b, 2014). As late as 2008, professional consensus on how education could stimulate inclusion remained elusive (Gilliland et al. 2008). The archival field traditionally hewed to a Eurocentric paradigm that elevated the fixed (viz., the written and the textual) and 
the chronological over the oral, performative, or multidimensional (Pluralizing the Archival Curriculum Group 2011).

Breaking with this tradition, Gilliland (2014) advocated instead for pluralism"acknowledging, respecting, and addressing the multiplicity of perspectives, practices, and people involved in the creation, preservation, use, and interrogation of their records in society today" (p. 236). Pluralism accommodated variegated, intersecting perspectives, e.g., race and ethnicity, culture, class, gender and sexuality, religion, disability, and citizenship status (Pluralizing the Archival Curriculum Group 2011).

A pluralist pedagogy revolved around culturally sensitive, responsive, and inclusive (Indigenous, local, global) archival curricula leavened by ongoing reciprocal education and reflexivity (Gilliland et al. 2008; Pluralizing the Archival Curriculum Group 2011). Key topics included multidisciplinarity, social justice, neutrality, Indigenous sovereignty, digital repatriation, truth and reconciliation commissions, community engagement and archiving, service learning, personal digital archiving, and digital media (Gilliland 2014, 2011; Pluralizing the Archival Curriculum Group 2011).

For example, White's (2009) pluralizing framework involved conceptual expansion, community embeddedness, equitable collaboration, leadership, activism, and ethics, reflexivity, and sustainability. In addition to constituting a space to integrate the community's interests, needs, and cultural beliefs, e.g., into curriculum design, community engagement potentially offered a source for new LIS students and faculty (White 2009).

But challenges of a pluralized curriculum also emerged, for example finding examples and case studies, as well as practica sites, developing targeted material for nondominant language communities, and including oral traditions and an increased range of record types and formats (Pluralizing the Archival Curriculum Group 2011).

\section{Digital technology}

As Breck (1966) contended, the aftermath of the Second World War offered watershed opportunities and responsibilities for data collection and dissemination-and thus for archiving. Colson (1968) soon underscored the potential of the computer as the most consequential issue facing the profession.

But no paradigm shift embracing these new technological realities and the pedagogy necessary to accommodate them occurred. Stielow (1985) warned, "The danger for archivists is that they will be bypassed by technology and relegated to antiquarian status - the medieval monks of a post-industrial society" (p. 13). Technology, he insisted, demanded lifelong learning midwifed through specialized educational programs.

Weber (1988) hailed new technology-enabled possibilities and responsibilities. Computers could help archivists obtain better control over their materials, namely through automation and increasing acceptance of the MARC (MAchine-Readable Cataloging) format. She called attention to new technologies (artificial intelligence 
systems, high speed text search systems, text conversion capabilities) and applications (word processing, database management, online searching). Necessary education implied risk-taking but remained essential to the profession's viability.

Like Weber, Eastwood (1988) lobbied archivists to embrace instead of fear or stave off automation, not least because of its inescapable effects on recordkeeping information retrieval, management, and use. He recommended teaching the basic concepts and practices of automation and machine-readable archives across the curriculum.

Even as scholars such as Eastwood, Weber, and Stielow encouraged the field to embrace technology, some urged caution. Society of American Archivists (SAA) president Joyce (1988), for one, reminded archivists to "avoid being unduly directed by the technological imperative" (p. 21).

Gabehart (1992) conducted the first empirical study of archivists' education in computer automation. More than a quarter (128, or $28.1 \%$ ) of 456 respondents believed education for computer automation "fairly important," the most frequent response overall. When asked to speculate on the issue five years hence, however, more than half $(237$, or $52.3 \%)$ of 453 selected "very important," the most frequent response overall.

Given the increasing remit of automation, Cox (1993) lamented the lack of viable graduate or continuing educational structures for electronic records management (ERM). Additionally, Hedstrom (1993) pointed out that the profession had considered electronic records and automated techniques nominally; she urged ongoing education and training to fill this gap. Curriculum development challenges arose from information technology, automation, electronic records, theory, and both basic concepts and terminology and evolving methods and practices (Hedstrom 1993). The profession's lack of standard practices in ERM (appraisal, description and preservation of databases, automated office documents, or digital cartography), and automated techniques (hypermedia systems or artificial intelligence) Hedstrom found particularly troubling.

The apparent slowness of archivists to embrace technology education led Stielow (1993) to muse, "the archival mindset has been rooted in the humanities and often appears uncomfortable with presentist concerns" (p. 49). Seeking balance, Kesner (1993) suggested that an archivist did not need to be a "technologist," but rather must appreciate information technologies' benefits for her work. Both he and Stielow (1993) called for a pedagogy that synthesized traditional skills, methods, and values with information technology. Propitiously, Stielow's 1992 survey of 12 regular faculty with responsibilities for archives programs indicated that all twelve educators' programs offered course work on automation and the MARC format; the vast majority also touched on machine-readable files (Stielow 1993).

By the middle of the 1990s, a consensus on the urgency of embracing technology seemed at hand (Couture 1996). Nesmith (1996) called it "the greatest challenge the archival profession has ever faced" (p. 91), and Craig (1996) characterized the role of technology in record-making as effectively unprecedented.

But a decade later, preparing students technologically still vexed educators, even as the latter agreed on its necessity (Bastian 2006; Cox 2006). Eastwood (2006) maintained that students needed a deep understanding of information technology 
to determine what hardware, software, and storage media met professional needs. Instructors themselves needed to master technology—and be able to explain it, he insisted. Noting that the number of new technologies to master increased yearly, Tibbo (2006) bemoaned archival programs' scant attention to technology (e.g., information systems, electronic records and databases, record migration, digitization, and web design). At minimum, students needed to know how to deal with systems and product vendors, e.g., online catalogs and database systems. Tibbo's (2006) analysis of eighteen archival education programs concluded that few graduate students could take many information technology courses. Paradoxically, as Gilliland et al.'s (2008) respondents suggested, electronic or digital records management numbered among the most important areas to incorporate in the curriculum.

By the 2010s, digital technology seemed ineluctable, even in a field traditionally permeated by "technophobia" stemming from its preservation mandate (Cox 2009, 2012). Digital curation emerged as a central priority; projects proliferated across the disciplines to safeguard or rescue social, cultural, educational, scientific, and economic assets (Cox 2012; Tibbo 2012). Digital curation even seemed a potential locus for archival education (Cox 2012). Sundry graduate education initiatives, though often funded short-term and by soft-money, attested to this optimism (Anderson et al. 2011; Bastian et al. 2010, 2011; Botticelli et al. 2011; Fulton et al. 2011; Galloway 2011; Gregory and Guss 2011; Harvey and Bastian 2012; Kelly et al. 2013; Kim et al. 2011; Lee 2009; Lyon and Brenner 2015; Mayernik et al. 2015; Moen et al. 2012; Palmer et al. 2008; Renear et al. 2009; Yakel et al. 2011).

But although the number of curation educational opportunities spurted at both graduate and professional levels, no consensus prevailed on the curriculum, students remained chary of technical courses, and a continuing lack of continuing education exacerbated matters (Tibbo 2012). Further, few programs required digital curationrelated coursework and few faculty specialized in the area (Tibbo 2015). Tibbo (2015) nonetheless predicted the eventual integration of digital curation into the core iSchool curriculum, in which "distinctions such as 'digital' curation will be dropped" (p. 151), and Cox (2015), too, foresaw archival education becoming, in effect, education for digital curation.

\section{Sustainability}

Not only developing but also sustaining archival education persists as a scholarly concern; unsurprisingly, it dates to the 1930s birth of the profession. The career of American University's archival education program, which foundered after Ernst Posner's 1961 retirement, testified to the fragility of even a seemingly robust program (Cox et al. 2001a; Ross 1981; Zhang 2015).

The sustainability of archival programs also hinged on broader changes in higher education. As Burke (1992) noted, "The tragic economic condition of the educational establishment...does not bode well for innovation or renovation" (p. 536). More important, the emergence of the neoliberal-cum-corporate university compelled educators to focus on the bottom line, which in turn depended upon funded research and various quantitative measurements (e.g., assessments and benchmarks) 
(Cox 2009; Leazer 2016). This weltanschauung supplanted seemingly archaic notions of societal betterment (Cox 2009).

In the $2010 \mathrm{~s}$, concern festered still. Hobbled by its inveterate association with the humanities, the field faced fewer grant funding opportunities and relatively low salaries overall. Further, administrators seemed likely to funnel their meager resources into trendy areas, namely Big Data, to try to attract outside funding (Cox 2015). Cox (2015) believed the future viability of graduate archival education imperiled.

\section{Doctoral education}

North American archival doctoral education remained nascent even as Duranti and Gilliland-Swetland (1999) discerned manifest demand for faculty. The demand for faculty had increased over the previous three decades. At the close of the 1970s, for example, there were three full-time faculty in LIS and four in history. In 1989, there were 12 LIS and nine in history. By the beginning of the new millennium, there were 26 in LIS, and 11 in history (Cox et al. 2001a).

As early as 2000, Cox (2000a) and likeminded educators pondered holding an annual conference to collaborate, to share research, and to provide a forum for $\mathrm{PhD}$ students, given the need to recruit and mentor the latter as potential new faculty (Cox et al. 2001a; Gilliland 2016). Despite their increasing numbers, archival educators felt isolated still; a meeting offered the opportunity to thrash out pressing technological, epistemological, and ethical challenges while building infrastructure for education and research (Gilliland 2016).

First convened in 2009, the Archival Education and Research Institute (AERI) began preparing a new generation of prospective faculty members (Cox 2015). AERI participants committed to working equitably to build the field; the event constituted "a working meeting, a catalyst, [and] an incubator" (Gilliland 2016, p. 29), involving mentoring and networking as well as socializing (Buchanan 2016). Similarly, Soyka and Wilczek (2020) characterized AERI as a national and increasingly international magnet for collaboration, community-building, leadership development, and scholarship.

\section{Enrollment}

Scholars generally dodge addressing meat and potatoes issues such as enrollment; what is more, data on enrollment and its ebb and flow over time is lacking. Eastwood (2017) argued that student recruitment depended upon the size and prestige of the profession. He pointed to a vicious circle: the size of the profession constrained education programs' development.

\section{Employment prospects}

Archival employment predictably rested on macroeconomic trends, namely the late 1960s expansion in higher education funding (Miller 2000). This led to a greater number of graduate history programs and archival jobs, especially in 
higher education institutions; ironically, the number of history teaching jobs did not increase. Hence, archival education found a new market (Miller 2000).

But this new market was amorphous; Joyce (1988) noted that educators possessed scant evidence what employers wanted from graduates. Cox (2000a) hit upon this point, seeing employers neglecting to offer substantive pedagogical input. He further contended that educators "do not receive very articulate answers" from practitioners about what the latter need; educators also faced "criticism and disdain for the conceptual or theoretical discourse" (p. 248). And if employers weighed in, Cox (2006) wrote acerbically, the graduate "should know everything (without the salaries enabling people to stay in school...to gain such knowledge)" (Cox 2006, p. 248). Like Cox, Eastwood (2006) acknowledged that educators generally understood that a gap persisted between their notion of knowledge development and employers' job skills wish list. Whereas educators believed skills were rooted in archival knowledge but came to fruition only in practice, employers expected graduates to effect a seamless transition into practice (Eastwood 2006).

Only a few studies concentrated on the realities of employment. GillilandSwetland (1998) characterized the job market as "fairly healthy," and as "stable or slightly increasing," albeit with some differences by geography and type of work. Conversely, she found some graduates accepting entry-level positions at miserly salaries.

Most of Gilliland-Swetland's (1998) respondents predicted future professional roles related to emerging technology; electronic records, digital asset, and information resources management; information policy; metadata; digital preservation; virtual curatorship; and online access, all in a context of more flexible career structures.

Cox (2000b) learned that experience remained the most desired job qualification; fully two thirds of the advertisements he examined sought it. He also examined the nature of entry-level archival work, finding increasing emphasis on computer literacy, descriptive standards, and computer applications even as the demand for special subject knowledge remained constant (Cox 2000b). This change in work was accompanied by another striking finding that higher education institutions were the dominant employer of these new graduates. Last, Cox found a "relative decline" for entry-level salaries, a distressing point that harkened to Gilliland-Swetland's (1998) concern.

Fully three-quarters (76.9\%) of Francis's (2015) 121 respondents claimed processing numbered among their core duties. This far outstripped the next two, digitization $(45.5 \%)$ and reference $(44.6 \%)$. Despite the profession's recent focus on born-digital records, just one-fifth $(20.7 \%)$ of respondents said working with born-digital records constituted a core responsibility.

Given this smattering of scholarship, it is no wonder Tansey (2015) called for more research not only into who archivists are, but also change over time in the employment market. Indeed, SAA president Zanish-Belcher (2019) called for more transparency, especially in job advertisements, about practitioners' salaries, especially data broken down by location and type of repository. 


\section{Methods}

Drawing from a larger study on the future of archival education in North America, this paper is based on a qualitative, exploratory case study. It examines complex current phenomena in-depth, thereby obtaining a holistic, "insider" perspective, with the goal of producing Geertzian thick description (Gorman and Clayton 2005; Pickard 2013a; Schwandt and Gates 2018; Yin 2009). We employed semistructured interviews, which yielded detailed, descriptive, specific data. They provided us access to the observations, perceptions, experiences, and interpretations of our participants. In reconstructing past events, understanding social and political processes, and obtaining descriptions of and feelings about current events, we integrated multiple perspectives to generate holistic interpretations (Pickard 2013b; Rubin and Rubin 2005; Weiss 1995).

We relied on purposive sampling to choose information-rich cases (Pickard 2013c). We sought to interview all full-time tenured or tenure-track faculty contacts for archival programs listed in the Society of American Archivists Directory of Archival Education. We conducted interviews with 33 of these educators between December 2020 and July 2021. Interviews ranged from 50 to $115 \mathrm{~min}$.

Primarily based at institutions in the USA (32 of 33; the other works at a Canadian institution), participants included twelve males, twenty females, and one nonbinary individual. Twenty-five participants are white, four are African American, two are Asian, one is Latinx, and one is Pacific Islander. Thirty-two of 33 have PhDs; their fields include LIS (20), History (8), American Civilization (1), Education (1), Organization and Management (1), and Archival and Book Heritage (1). Nine are Professors, twelve are Associate Professors, ten are Assistant Professors, one is an Assistant Teaching Professor, and one is a faculty member. ${ }^{1}$ Their years of faculty experience at the time of their interview ranged from less than one to 32. Most (28 of 33) hold positions in Information Science programs; the others work in History Departments.

We asked respondents specifically to discuss what they believed to be the key challenges and changes currently facing archival education. Our coding of these data progressed iteratively from initial/open to focused/axial (Charmaz 2014; Saldaña 2013). We employed the constant comparative method, which proceeded until saturation. Analysis was ongoing, iterative, inductive, and grounded (Corbin and Strauss 1990; Glaser and Strauss 2009).

In service of trustworthiness, we relied on multiple data sources; documentary evidence complemented our interview data (Bowen 2009; Hodder 2000; Prior 2003; Shenton 2013; Wildemuth 2009). Though not generalizable, our conclusions are potentially transferable (Pickard 2013a).

\footnotetext{
1 Our sample ultimately included three non-tenure-track faculty members. In one case, a program's tenured faculty member referred us to a non-tenure-track faculty member. In a second, we decided to interview a non-tenure-track faculty member because she directs the only Master of Archival Studies program in the USA. In a third, we interviewed an Associate Professor who, it tuned out, does not have tenure, only a long-term contract.
} 


\section{Findings}

Participants adduced six broad challenges facing archival education and educators: faculty issues, curriculum issues, interdisciplinarity and collaboration concerns, diversity, equity, and inclusion, digital technology, and sustainability.

\section{Faculty}

Faculty-related concerns included full-time faculty numbers, balancing teaching and research, and practitioner relationships.

\section{Faculty numbers}

Five interviewees (P17, P19, P21, P22, and P26) discussed faculty numbers. P17 insisted that archival studies comprised "part of a broader collection of fields, but it is unique, it has its own program, it has its own needs, and it needs a faculty." P22 and P26 bemoaned the paucity of full-time archives faculty at their programs.

Commenting on her program's recent hire of a second tenure-track archival educator, P21 looked forward to developing a seamless curriculum. To this point, P19 deemed her program fortunate to have two full-time faculty. She professed jealousy of the few programs with three or more archives faculty, whereas having only one seemed egregious. To increase archives coverage, P19's program was considering interdisciplinary hires who could teach archives as part of its overarching cultural heritage program.

\section{Balancing teaching and research}

Three participants (P18, P19, and P20) expressed concern over balancing teaching and research demands and priorities. Observing programs' increasing focus on research, P19 discerned a concomitant decrease on quality teaching and "keeping your [teaching] skill set sharp." But as she insisted, "that's what the students want and that's what the students need." Facing a similar dilemma, P18 contributed, "I don't understand how I'm supposed to be an active scholar, publish, and also keep up with new trends in archival practice." "Thank God for the adjuncts," she commented.

\section{The faculty/practitioner relationship}

Two participants (P10, P22) discussed the often fraught relationship between archival educators and practitioners. "The scholarly audience tends to be just a little turned off by the issues that interest professionals," commented P10; this was "a chasm that needs to be bridged."

P10 chided programs that excluded practical work, e.g., creating finding aids or processing papers, and expected students to obtain hands-on experience through internships. P10 feared "a point where the profession starts getting a little pissed off, 
where they're like, 'shit, you know the students coming in, I have to teach them everything." ' In her own teaching, by contrast, P10 embraced a hefty dose of practice as well as theory. Ironically, as she recalled, "I got criticized for it, like, 'oh, you're teaching people how to put together boxes,' and I'm not." Rather, "we put together the box because it allows us to move forward with the rest of our processing work."

In a similar vein, P22 worried about future faculty members lacking professional work experience. "One more generation out," she observed, "[faculty] could be separated quite dramatically from practice." Archival educators, P22 insisted, must balance professional and disciplinary priorities. To this end, she proposed a fellowship for faculty members who lacked recent hands-on archival work experience. Pausing their tenure clock, these faculty members would undertake intense practitioner work and bring this knowledge back to their students.

\section{Curriculum}

Pressing curriculum issues include content coverage, online instruction, and curriculum change.

\section{Content coverage}

Content coverage proved a challenge for fifteen participants (P2, P5, P6, P7, P11, P14, P15, P16, P17, P19, P22, P26, P30, P31, P32). Their concerns ranged widely. P5, for one, mused over what should constitute foundational curriculum content. "I go back and forth," she confessed, "someone can make the argument...how is knowing who Schellenberg or Jenkinson or Roscoe Hill [is]...going to help someone to be a better archivist or apply metadata to a record or develop an outreach program or community partnership."

Without exception, participants wrestled with a burgeoning amount of content but a circumscribed number of credit hours. As P6 specified, students must understand the "whole societal role of records, birth to death." P4 meanwhile found "more and more to learn - the field is getting bigger and bigger, and we don't have enough [curriculum] space." In similar spirit, P14 lamented, "You can only do so much with two instructors and a 15 week semester." Pinpointing the zero sum nature of archival curricula, P30 reflected that integrating a new topic demanded the subtraction of another one. "There's nothing I could see that's like, 'no, we don't need to be teaching them this anymore," she said ruefully.

Ultimately, as P31 explained, "The resource issue is always in the back of your mind, and it discourages grand thinking." She noted drily that resources wax and wane- "usually there's more waning than waxing"-and pointed to structural and organizational challenges that impeded curriculum expansion. Invoking the classic chicken and the egg conundrum, P32 added, "having the resources to broaden the curriculum would be critical, but you can't broaden the curriculum if you don't have the students for which you're broadening."

Given the challenges of curriculum coverage, three interviewees offered mitigating strategies. P14 relied on stopgap measures, for example addressing electronic 
records management as part of the broader ecology of records management. P11 suggested that a consortium of programs might collaboratively offer certain courses, while P7 advocated for integrating archival principles into core LIS courses such as metadata.

\section{Online teaching}

Six participants weighed in on online teaching (P2, P8, P9, P11, P15, P16). On the one hand, P15 fretted about the administration compelling her to teach online, which she thought a grievous mistake. "We have small classes, we have these possibilities for students to actually go work in an archive...in the building right next door...we can go...from the archive to our class [and] back." Reflecting on teaching remotely during the pandemic, she lamented, "students don't know each other, how much they get from just hanging out in the lab together." She believed that such community development could be replicated online, but cautioned that the current technological infrastructure for doing so remained a "disaster."

Five other participants (P2, P8, P9, P11, P16) accepted online learning as a fait accompli-and as an opportunity. Unlike P15, P16 contended that Zoom "saved" higher education; the platform "allowed us to face a pandemic and still move forward in many, many ways."

Both P8 and P11 noted that the pandemic hinted at the possibility not only for remote students, but also remote faculty. For P8, the pandemic accelerated a process that technology had already jumpstarted. P9 enjoined instructors not only to augment their online teaching skills, but also to determine how to provide experiential (e.g., practica) opportunities to remote students, a point with which P2 and P8 concurred. This P9 framed as "a real opportunity."

\section{Curriculum change}

Six participants discussed possible curriculum changes. Three (P15, P16, P20) foresaw change, however nebulous. P15, for example, claimed, "there's got to be changes, but I don't know what they're going to be." P16 also equivocated: "do I see changes, yes, definitely, do I see complete overhaul, maybe.” P20 elaborated, "I certainly hope there will be changes over the next ten years. It's an interesting time because people are really not willing to make a lot of changes during the pandemic. We're trying to maintain what we have and support the students who are here."

Conversely, three participants (P5, P14, P17) saw the future hewing to the status quo. Although she chuckled, "I'm not a very good visionary," P14 argued, "You don't need drastic [changes]. You don't need new courses. You just need to make sure that your current courses are up to date, especially with limited resources." Likewise, P17 predicted no major changes, only "little tweaks." Still another participant, P5, forecasted no major changes, but rather ramped up investment in the program's signature strengths, namely archives and public special collections. "Programs need to be very honest about what their strengths are," she concluded. 


\section{Interdisciplinarity and collaboration}

Eleven participants (P1, P3, P4, P5, P11, P15, P21, P22, P28, P30, P31) addressed interdisciplinarity, collaboration, or both. Surmounting the longstanding if now obsolete LIS/History debate, they adumbrated a much broader range of possibilities for interdisciplinary collaboration.

On the one hand, P4 found her program's curriculum brimming with it. "We work with forensic people, we work with lawyers, we work with computer scientists, we work with computer engineers, we work with anybody in the arts of any kind, political science, etc."

On the other hand, P1, P3, P5, P15, P21, P22, P28, P30, and P31 underscored the need to nurture such collaboration far more vigorously. P30, for instance, enthused that "the intersection of public history and archives... has been getting bigger and bigger and bigger." In like mind, P21 favored cultivating deeper connections with public, applied, and digital humanities, P5 with digital humanities, and P15 with digital history.

New or renewed partnerships with the humanities notwithstanding, P22 insisted on the need to develop partnerships with burgeoning areas such as the health professions and information technology. She elaborated, "I have a liberal arts background and I love liberal arts, [but] we need to...enrich our curriculum with perspectives from those growth areas," as they seemed essential for future employment and for program sustainability.

Despite interviewees' plugs for interdisciplinarity and collaboration, P31 sagaciously noted, "everything's so fluid...the whole museum, archives, library boundaries are collapsing." As a result, maintaining an "archival identity" represented a formidable challenge. Deciding when to cross disciplinary boundaries and collaborate to her remained an unsettled issue.

\section{Diversity, equity, and inclusion (DEI)}

Thirteen of 33 interviewees foregrounded diversity, equity, and inclusion. They discussed educators' own training, recruitment, curriculum change, and future directions for DEI in archival pedagogy.

P25 castigated the academic preparation of many archival educators. Steeped in the myth of technological neutrality, these educators, she posited, lacked exposure to race, culture, and social justice topics. This led to an unfortunate snowball effect because educators produce students based on their own educational experience. Therefore, P25 called for a fundamental change in archival education. Not restricted to the curriculum, this overhaul demanded an overarching institutional and programmatic commitment to diversity, equity, and inclusion anchored in strategic planning.

P18, P25, P8, and P22 surfaced student recruitment in service of DEI. Citing race, ethnicity, age, and socioeconomic class, P18 underlined the challenge of recruiting diverse students who in turn would diversify practice. To this point, P25 noted, "A lot of people have preconceived ideas of what an archive is, and if you don't try to change that...you're not going to attract [diverse] folks." In similar spirit, P8 lobbied 
for more focused recruitment of diverse students and faculty_ "intentional and open without any kind of bias, just like, 'Hey, this is for everyone,' not just certain underrepresented races or ethnicities." P8 encouraged the use of multiple recruitment channels too, especially social media.

Eight interviewees addressed DEI in the context of curriculum change. According to P24, Eurocentrism and whiteness historically dominated archival education. Pointing to the salubrious emergence of African, indigenous, and community-based archival and recordkeeping traditions, she nonetheless equivocated, "like a big ship that's been sailing in one direction for a really long time... it takes a long time to turn something big that's been moving in one direction."

By contrast, P10 thought archival educators occupied the vanguard of DEI pedagogy. "I'm always trying to incorporate new [DEI] material," she elaborated. "My students are definitely hungry for it and if you don't do it, you're in trouble." In like mind, P13 opined, "our citizenry is changing, and we have to change too." "Our younger archivists are coming out with that mindset that we've got to be more inclusive," she reflected. P32 also pushed for expanding students' archival activism under the auspices of social conscientiousness.

Looking forward, P14 saw DEI playing an increasingly vibrant role in boarder conversations about arrangement, description, preservation, social media platforms, and community archives. Likewise, P1 foresaw her program's curriculum continuing to center social justice, ethics, democracy, hierarchies of power, and representation as part of promoting a just society and combating the profession's colonial legacy. P27, too, predicted further curricular decolonization. Finally, P22 called for attention to diverse archival program sustainability, viz., ensuring the survival of smaller and/or boutique programs, not only large, well-funded ones.

\section{Digital technology}

Twenty-four of 33 educators weighed in on digital technology. They defined technology capaciously if not ambiguously-encompassing the hardware and software that produced or digitized content and that enabled it to be archived. Key foci included being proactive, keeping abreast of technological developments, fitting technology instruction into the curriculum, the continuing importance of analog material, and future directions and predictions.

Educators such as P26 bemoaned archival educators' far from proactive embrace of the digital. P22 advised bluntly, "programs have to be dealing with digital everything, and if an archival education program is not doing that already, they need to be thinking about it."

Given the proliferation of born-digital as well as digitized records, P30 insisted that fluency in digital methods was crucial. Yet she feared her curriculum had failed to keep pace with this need. For her part, P29 quipped, "what sort of media are we going to be producing archives in next that I'm not going to be prepared [to teach]?" Paralleling P29, P14, P23, and P28 deemed their most formidable challenge keeping up with digital developments; P11 posited that the celerity of technological change demanded lifelong learning and worried that senior professors were likely to fall 
behind. P18, an early career professor, however, struggled to keep up with technology; as she put it, "I don't understand how I'm supposed to be an active scholar, publish, and also keep up with new trends in archival practice." P23 also admitted to feeling "very siloed."

Exacerbating the challenge of staying up to date, educators such as P30 deliberated over how to shoehorn technology into her program's surfeited curriculum. “There's nothing I could see that's like, 'no, we don't need to be teaching [students] this anymore,'" she lamented. In much the same way, P15 wished she could cover digital archives in more depth, and P16 pointed to the challenge of addressing robustly the "push me, pull you" dynamic between digital technology and traditional (read: analog) archival principles and practices. Seeking a lowest common denominator, P3 called for basic introductory technology benchmarks for students. "I can't necessarily expect them to become programmers," she stipulated, but she wanted to prepare them at least to deal capably with technology vendors.

Looking ahead, P33 envisioned a curriculum increasingly dedicated to the digital; she advocated for a more data-oriented approach in archival studies. Similarly, P19 predicted digital records would become ever more integrated with her program's curriculum. "We don't have a choice living in a digital world," she insisted, a point affirmed by P26. As part and parcel of this evolution, P19 also forecasted that students would need to embrace artificial intelligence and related fields; given the traditional humanities backgrounds of many students, this could be discomfiting. Thinking holistically, P13 strove to prepare her students "to know what technology can do well and where humans belong and how they fit." Educators must ensure students understand, not black box, new technologies, P2 maintained.

Despite this overriding focus on technology, P31 pointed out that an immense amount of analog material remained. This "can't be given short shrift as we rush to turn ourselves into digital curators." Even so, as P26 insisted, paper would become secondary. In this vein, P10 surmised that in the near future, "digital archives" would simply become "archives." Such a paradigm shift seemed imperative to P6, who warned, "If the archival field cannot adapt to working as a digital field...it will simply become the backwater."

\section{Sustainability}

Key themes related to sustainability included the next generation of faculty, program funding, enrollment, the job market and alternative career paths, and outreach and awareness.

\section{New faculty}

Five educators (P6, P20, P24, P26, P27) pointed to the elemental challenge of archival studies' sustainability. Among the earliest full-time tenure-track archival educators, P6 feared for the solvency of archival education. She recalled a dispersed smattering of educators when she obtained her faculty position. By the 2010s, there were a relatively large number of archival educators globally, which AERI encouraged. 
But demographics obtruded, as the cohort of educators of her generation began retiring. "It's not in the hands of people like me any longer," P6 remonstrated. "It's in the hands of the generations behind me."

P6 lamented, too, that many stakeholders failed to apprehend the newness of archival studies as a field, much less the "legwork" necessary to perpetuate it. She elaborated, "somebody has to be watching the shop and they have to be building those relationships with repositories and with professional organizations and they need to understand the history of the field, where it's come from and where it's going." She predicted that in the upcoming decade, many programs would face perhaps insuperable solvency problems.

Like P6, senior faculty member P27 expressed pessimism. "I'm afraid archival education is going to be a thing of the past," she noted. "I don't see the line of new professors coming up." She characterized AERI as quite disappointing in this regard.

Even more pessimistic than P6 and P27, senior faculty member P26 felt "globally worried" about LIS education overall. Having witnessed the diminution of LIS programs when they merge with or were absorbed by other programs, she admitted, "I can easily see library, not just archives, programs relegated to second- or third-tier institutions."

In line with senior faculty's concerns, junior faculty member P20 deemed succession planning the field's most pressing challenge. Another junior faculty member, P24, hailed the diligent capacity-building work of the earlier generation, and worried about squandering that inheritance. "I have faith and confidence in [the younger generation of faculty]," she noted, "but I also know that a lot of us are still untenured, and...we don't have the institutional power."

P24 thought it essential to maintain strong doctoral programs to support the next generation of archival educators. "I'm a little bit concerned," she conceded. Apropos of sustainability, both P20 and P24 centered the Archival Education and Research Institute (AERI). P20 insisted, "I want to be sure that the students that attend AERI see a future for being an archival educator and that's been a challenge recently because it's a big world of information science and it's so easy to move away from archives."

\section{Funding}

Five educators (P4, P17, P22, P28, P29) cited funding issues as their biggest challenge. More broadly, P4 lambasted the cost of all US-based archival programs, especially because archival jobs paid relatively little.

Four participants pointed to more granular, program-level budgetary concerns. P17 tabbed university funding, i.e., "everybody's fighting over a smaller and smaller chunk." Her program resorted to alternative revenue streams as a sop. P29 meanwhile taught nearly half the courses in her program; because of this, her program's financial position remained sound. Nonetheless, her university was capitalizing on faculty departures and retirements to truncate faculty lines. Likewise, she noted that problems could arise if administrators decided to trim the ranks of adjuncts. The prospect of cuts therefore remained a Damoclean sword. 
P28 foresaw new costs accruing to programs, for example cloud storage, and worried over how best to justify such new costs to administrators. P22, finally, expressed concern not only over the cost of the technology students needed to learn and its infrastructural overhead, but also the faculty needed to cover ever-multiplying content areas.

\section{Enrollment}

Seven participants (P2, P15, P18, P19, P29, P31, P32) broached the challenge of enrollment. On one hand, P29's program maintained relatively steady enrollment because of its wholly online format, obviating the need for students to relocate geographically, and its relatively short duration (18 credit hours).

On the other hand, P15 characterized her institution's administration as "a huge challenge" given their overriding focus on enrollment. Like P15, P31 also worried about attracting students. P2's program mandated a threshold number of students to avoid cancelation; hence, course coverage remained inextricable from enrollment concerns. In similar spirit, P32 added, "having the resources to broaden the curriculum would be critical, but you can't broaden the curriculum if you don't have the students for which you're broadening."

Also looking at enrollment concerns, P19 pointed to broader demographic shifts that augured fewer undergraduate students. This, she predicted, would eventually result in fewer applicants. "We're in a bit of a sustaining mode," she confessed. P18 noted the challenge of reining in tuition increases. She foresaw an increasing portion of her curriculum migrating online for somewhat cynical recruitment purposes. "That's coming whether we want it or not," P18 maintained; "if we don't maintain growth in terms of enrollment, we're going to be in trouble."

\section{The job market and transferrable skills for alternative careers}

Nine educators (P1, P7, P11, P12, P13, P21, P22, P30, P31) discussed prospective employment - "the challenge of the marketplace" (P31). Eight (P1, P4, P9, P11, P12, P13, P22, P33) highlighted the transferrable skills of archives students and the allure of alternative careers.

The job market seemed far from auspicious for P18, who observed, "if you're getting saddled with $\$ 80,000$ in debt for an MLIS, and then you go into an uncertain job market, that's a big problem." In similar spirit, P30 reflected, "we're training students for jobs that don't exist"; like P18, she underlined the ethical implications of doing so. Indeed, P12 branded the dearth of good jobs for her graduates-not merely grant-funded, temporary, or part-time positions-nothing short of an "existential issue." This situation "breaks my heart," stated P7; she called upon employers to develop full-time positions.

In the face of employment challenges, eight educators recommended students parlay their skills into alternative careers. P33 thought archival educators could do a far better job funneling students into nontraditional areas that might benefit from archival skills. P11 saw opportunity for archives students in information management, which she defined as a fusion of archives management, records management, 
and library science. "People are in business to make money," P13 insisted. "Their goals aren't, 'I've got to keep great records."' As such, she enjoined educators and students alike to jettison their traditional myopic mindset. "You're a knowledge worker, that's your title," P13 insisted peremptorily. Suggested alternative career tracks included data governance, knowledge management, and cybersecurity. In much the same way, P22 linked archival programs' sustainability to graduates' ability to improve businesses' balance sheets. She advocated for alternative careers involving, for instance, information governance.

\section{The societal value of archives}

Three participants also connected sustainability issues to broader concerns regarding archival awareness among members of the public (P6, P21, P32). P6 noted that the term archives "is so sexy in so many fields at the moment, but...people still don't understand how much real expertise it takes to be an archivist, and I'm not sure that everybody really appreciates the kinds of pressures that archivists are subject to." P32 also saw "an identity problem," namely the public's lack of understanding of the importance of archivists' work. She encouraged stakeholders to develop compelling justifications for the indispensability of archival programs to ensure the preservation and accessibility of information. P21 lobbied for outreach programs to raise public awareness in just this way.

\section{Discussion}

Both Conway (1988) and Cox (1990a, b, 2006) underlined the continuity of many archival education concerns over time. This research complicates their assertions.

First, participants made scant mention of topics that historically pervaded the literature on archival education. These include the appropriate host program for archival education (LIS vs. History), integrating theory and practice (Conway et al. 2011; Cook 2000; Davis 1989; Schaeffer 1994), individual or program accreditation or certification (Conway 1988; Cox 2000b, 1993, 1990a, 1990b, 1986; Cox and Larsen 2008; Davis 1989; Gabehart 1992; Geary 1979; Kahn et al. 1975; Maher 1988; Miller 2000; Peterson et al. 1977; Stielow 1993; Tibbo 2006; Weber 1988; Wosh 1982), educational guidelines ("Archives Education Guidelines Approved," 1977; "Guidelines for a Graduate Program in Archival Studies," 2002; "Society of American Archivists Guidelines for Graduate Archival Education Programs," 1988; Benoit and Force 2019), a separate Master's degree (Cox 1993; Cox et al. 2001b; Duranti 1993; Eastwood 2017, 1988; Tibbo 2006), curriculum standardization (Couture 1996; Schellenberg 1968; Stielow 1993; Tibbo 2012, 2006; Wosh 1982), professionalization (Bastian and Yakel 2005; Breck 1966; Brooks 1951; Burke 1981, 1983, 1976; Colson 1973, 1968; Cox 2012, 1986; Davis 1989; Duranti 1993; Eastwood 1988; Freeman 1991; Helmuth 1981; Jones 1968; Joyce 1988; Kahn 1971; Maher 1988; Martin 1994; McCrank 1980; Miller 2000; Newsome 1939; Peterson et al. 1977; Schaeffer 1994; Smith 1994, 1974; Stielow 1993; Welch 1975; Wosh 1982), and experiential education such as the practicum (Berner 1981; Bower 1977; Cox 
1990a, 1990b; Eastwood 2006; Helmuth 1981; LeFurgy 1981; Mason 1972; Posner 1967; Stielow 1990; Tibbo 2015; Trever 1948).

Second, participants extended scholarly conversations related to faculty, curriculum, interdisciplinarity and collaboration, DEI, technology, and sustainability.

\section{Faculty issues}

In line with Burke (1981) and Conway (1988), study participants universally recognized the need for full-time tenured or tenure-track faculty. In contrast to many earlier writers, these participants did not weigh in on the importance of whether practical experience remained an essential qualification for educators.

Acknowledging the pressures of the neoliberal, corporatist university as noted by Cox (2009), interviewees found themselves hard-pressed to balance teaching and research. While always peculiar (Cox 1994; Stielow 1993), the practitioner/faculty relationship remains fraught. Even as faculty developed academic research agendas and concomitant institutional respect, they may well have further separated themselves from practitioners. SAA's burgeoning role in continuing education, which involves few full-time tenured or tenure-track faculty, further militates against pedagogical cross-pollination (https://www2.archivists.org/prof-education/continuingeducation).

\section{Curriculum issues}

Although content coverage has long been a challenge given archival studies' precarious place in the academy (Bower 1977; Tibbo 2006), it has metastasized further even, paradoxically, as both the number of courses and the number of full-time tenure or tenure-track faculty have increased. LIS courses have apparently not integrated archival content. Digital curation may facilitate this coming together (Cox 2012), but evidence is wanting.

Given the increasing prevalence of online education (Association of Library and Information Science Education 2021), not least because of Covid-19, participants underlined the need to investigate how best to adapt to - and to flourish in - this space. Perhaps surprising, despite their pointing to manifest current changes and challenges, participants generally did not foresee substantial curriculum change.

\section{Interdisciplinarity and collaboration}

As ever, interdisciplinarity is thriving in archival studies. Paradoxically, although other disciplines increasingly employ_and perhaps exploit—-terms such as archives and archiving (Blouin 1999; Manoff 2004), they have failed to build appreciable bridges with archival studies. Participants stressed the need for more interdisciplinary collaboration not only with humanities disciplines, but also with untapped resource-rich fields such as the health professions. As Eastwood (1988) reminds us, archivists "are children and servants of many disciplines, and that is their glory, not 
their intellectual disability" (p. 238); an optimum archival education would be thoroughly interdisciplinary (Tibbo 1997).

Although scholars frequently adduce the likelihood of convergence under the auspices of digital curation, it is far from clear whether such convergence has occurred, first, and second, whether it has redounded to the benefit of the discipline.

\section{Diversity, equity, and inclusion}

Participants pointed to an extraordinary uptick of interest in DEI issues, one that has occurred in a brief period. The need to increase demographic diversity in all areas of archival studies remains exigent. For instance, a 2017 survey conducted by the Women Archivists Section (WArS) garnered 2170 responses (including both SAA members and non-members). This sample was $84.3 \%$ female, $87.7 \%$ white, $3.1 \%$ African American, 3.6\% Latinx, and 3.2\% biracial or multiracial (Israel and Eyre 2017).

Given this demographic skew, recent SAA presidents underlined DEI as an urgent professional priority (Evans 2020, 2021; McGovern 2018; Meissner 2017; ZanishBelcher 2019). Likewise, the Society of American Archivists also ramped up overt support for DEI, e.g., SAA Council Statement on Black Lives and Archives (https:// www2.archivists.org/statements/saa-council-statement-on-black-lives-and-archives).

\section{Digital technology}

As this research suggests, although there are few required courses in digital curation and related topics, educators agree on the importance of teaching digital technology. At the same time, however, they struggle with how to teach it, and with what platforms to teach, particularly given resource and technical support constraints-which the advent of Covid exacerbated. Instructors may settle for sandboxes as a result. Because of resource constraints, teaching technology remains especially challenging for online programs.

Another issue with technology is balancing training in digital and analog content. A preternatural amount of analog content persists, as the hue and cry triggered by More Product, Less Process attested (Greene 2010; Greene and Meissner 2005; Meissner and Greene 2010). In fact, conventional processing dominates the core duties of entry-level professionals (Francis 2015).

Still another issue is the celerity of change in digital technology and its implications for pedagogy. Hedstrom's 1993 assertion, highlighting a Catch-22 in technology pedagogy, remains relevant:

If the profession acts now on the basis of current theory, practice, and technology, we risk developing a curriculum that is inadequate and that will rapidly become obsolete. If we wait until the archival and automation issues are resolved, until the technology stabilizes, or until specialists develop solutions to most automation issues, we may abdicate responsibility for determining the profession's response to automation to a small group of experts and drive a 
wedge between specialists in electronic records or automation and the rest of the profession" (p. 428).

A final issue is the need not merely to teach technology, but to teach it critically. Educators should theorize technology in archival education, embracing an STS perspective and prying open innumerable black boxes (Star 1995, 1988; Van House 2005).

\section{Sustainability}

The sustainability of archival education loomed large. Originally funded by IMLS, AERI, a key pipeline for future faculty, continues, albeit ad hoc and without dedicated support; its fate remains perennially unclear.

The ascent of the corporate university has put ever more pressure on faculty not only to conduct more research, but to obtain external research funding. Archival studies's status in universities depends upon their faculty's research productivity; administrators regard such output as far more prestigious than the mere training of practitioners (Leazer 2016). This likely exacerbates faculty members' ability to keep abreast of the latest trends in practice and therefore militates against a more harmonious relationships between practitioners and faculty.

Another sustainability concern is the challenge of obtaining financial information (e.g., about enrollment or employment); this dates to the earliest study of archival education (Warner 1972). Apropos of enrollment, archival studies lacks an analog to the Association of Library and Information Science Educators' (ALISE's) annual report. Excepting a scattering of studies on job advertisements, an accurate picture of the employment market remains elusive. This is particularly important since as the WaRS data showed, although $44.43 \%$ of respondents were currently "able to get ahead or comfortably situated," nearly half (48.11\%) were only "getting by," and 7.45\% were "struggling" (Israel and Eyre 2017).

Still another sustainability concern arises from the need to broaden students' perceptions of potential employment venues. This requires, however, that faculty need to break free of their traditional scholarly and professional networks and develop and subsequently introduce students to new avenues. Again, given the research focus of the neoliberal university, this will constitute an enormous challenge.

Finally, raising awareness in service of sustainability remains a vital challenge. Notwithstanding the cachet of the term "archiving" or "curation," there seems a persistent lack of understanding of what archivists can do in both public and academic spheres (Connor 1943; Kahn 1971; Roe 2016).

\section{Conclusion}

Interviewees offered diverse prognostications about the future of archival education. On the one hand, P1 enthused, "looking ahead, I see a lot of opportunity." More guardedly optimistic, P31 characterized the archival education landscape as 
vastly different from the early 1990s. Most important, she noted the proliferation of full-time tenured or tenure-track faculty members in North America. Although she did not anticipate similar growth in the future, she nevertheless observed, "we have become a presence in [LIS] programs across the country and acknowledged as an important aspect of things."

Conversely, other participants appeared far less sanguine. "I'm just concerned, and I'm an optimist," P32 admitted. P20 added, "I want to reinforce what we have, and things are working okay, don't break them." Even so, she cautioned, "we have to change...the only way we'll keep people in our space is to meet their needs."

Future research might address eight questions. First, how will Covid-19 impact archival education long-term? Both P24 and P16 wondered how the pandemic would change professional work, for example how users would access archival materials. In this vein, P16 professed herself "very curious to see what the new normal looks like."

Second, the lack of scholarship on online archival education remains both surprising and troubling. How might educators develop best practices for online education?

Third, archival educators lack robust enrollment and employment (both archives and alternative careers) data. Given neoliberal higher education's dependence upon numbers, however specious, program directors would do well to make a more compelling quantitative argument for their programs' importance to their hosts. A project akin to ALISE's annual statistical report would be useful.

Fourth, this research centers on program directors, many of whom are senior faculty and all of whom are tenured or on the tenure track. What do doctoral students, adjuncts, and junior faculty perceive as the key challenges and changes in archival education?

Fifth, digital technology education is among the most pressing issues for archival educators. What are the most relevant technology platforms for students to learn as part of their graduate education and why? How can technology best be taught both in-person and online? How can educators provide a sound technology education despite the acknowledged lack of funding for platforms (and thus reliance on sandboxes), platforms' generally steep and thus time-intensive learning curves, and programs' general lack of technical support, especially for distance learners?

Sixth, the skyrocketing importance of DEI demands further inquiry. In line with Poole (2017a), scholars might further explore recruitment, retention, and mentoring-including faculty as well as students. An analysis of DEI content in archival courses would be welcome.

Seventh, what are the prospects for cooperative education? Possible partners include other graduate programs and professional organizations whether national, regional, or local. Such an endeavor would presumably reduce the longstanding friction between practitioners and faculty members.

Eighth, does institutional classification (e.g., Carnegie) impact archival programs' faculty teaching and research expectations, course offerings, instructional approaches, and relationship with the profession writ large? 
Despite manifest challenges and unanswered questions, archival educators remained undaunted. "I want [archival education] to succeed," P27 emphasized. "We have a lot to contribute to the academy."

Acknowledgements This project was made possible in part by the Institute of Museum and Library Services (re-246422-ols-20). We would like to thank our 33 participants for so generously carving out time to speak with us.

\section{References}

Anderson K, Bastian J, Harvey R, Plum T, Samuelsson G (2011) Teaching to trust: how a virtual archives and preservation curriculum laboratory creates a global education community? Arch Sci 11:349372. https://doi.org/10.1007/s10502-011-9157-y

Archives Education Guidelines Approved (1977) SAA Newsletter 4-5

Association of Library and Information Science Education (2021) 2020 statistical report. Association of Library and Information Science Educators, Westford, MA

Bastian JA (2006) Introduction to the Archival Science special issue on graduate archival education. Arch Sci 6:131-132. https://doi.org/10.1007/s10502-006-9023-5

Bastian JA, Yakel E (2005) "Are We There Yet?" Professionalism and the development of an archival core curriculum in the United States. J Educ Libr Inf Sci 46:95. https://doi.org/10.2307/40323864

Bastian JA, Yakel E (2006) Towards the development of an archival core curriculum: the United States and Canada. Arch Sci 6:133-150. https://doi.org/10.1007/s10502-006-9024-4

Bastian JA, Harvey R, Mahard M, Plum T (2010) Building a virtual archives and preservation curriculum laboratory at simmons college. J Educ Libr Inf Sci 51:241-250

Bastian JA, Cloonan MV, Harvey R (2011) From teacher to learner to user: developing a digital stewardship pedagogy. Libr Trends 59:607-622. https://doi.org/10.1353/lib.2011.0012

Bauer G (1955) Recruitment, training, and promotion in the national archives. Am Arch 18:291-305. https://doi.org/10.17723/aarc.18.4.d24474101513276g

Bemis S (1939) The training of archivists in the United States. Am Arch 2:154-161. https://doi.org/10. 17723/aarc.2.3.r1ht0v6740rp3053

Benoit E, Force DC (2019) One size does not fit all: graduate archival education in the twenty-first century. Am Arch 82:24-52. https://doi.org/10.17723/0360-9081-82.1.24

Berner RC (1981) Archival education and training in the United States, 1937 to present. J Educ Librariansh 22:3-19

Blouin FX (1999) Archivists, mediation, and constructs of social memory. Arch Issues 24:101-112

Boles F (1990) Archival education: basic characteristics and core curriculum. Perspect Hist

Boles F (1996) Making hard choices: continuing education and the archival profession. Arch Issues 22:7-24

Botticelli P, Fulton B, Pearce-Moses R, Szuter C, Watters P (2011) Educating digital curators: challenges and opportunities. IJDC 6:146-164. https://doi.org/10.2218/ijdc.v6i2.193

Bowen GA (2009) Document analysis as a qualitative research method. Qual Res J 9:27-40. https://doi. org/10.3316/QRJ0902027

Bower AS (1977) Whence and whither: a survey of archival education. Ga Arch 5:44-61

Breck A (1966) New dimensions in the education of American archivists. Am Arch 29:173-186. https:// doi.org/10.17723/aarc.29.2.436288j768u82835

Brooks P (1951) Archivists and their colleagues: common denominators. Am Arch 14:33-45. https://doi. org/10.17723/aarc.14.1.k21808840h110k03

Buchanan SA (2016) AERI as a catalyst for archival doctoral education. Preserv Dig Technol Cult 45:3238. https://doi.org/10.1515/pdtc-2016-0001

Buck S (1941) The training of American archivists. Am Arch 4:84-90. https://doi.org/10.17723/aarc.4.2. u652un52g5231278

Burke FG (1976) Similarities and differences. In: Clark RL Jr (ed) Archive-library relations. R.R. Bowker Company, New York, NY, pp 31-68 
Burke F (1981) The future course of archival theory in the United States. Am Arch 44:40-46. https://doi. org/10.17723/aarc.44.1.4853801307551286

Burke FG (1983) Archival cooperation. Am Arch 46:293-305. https://doi.org/10.17723/aarc.46.3.u5715 88787 n88q81

Burke FG (1992) Letting sleeping dogmas lie. Am Arch 55:530-537. https://doi.org/10.17723/aarc.55.4. w628m34076646275

Charmaz K (2014) Constructing grounded theory, 2nd edn. Introducing qualitative methods. Sage, London ; Thousand Oaks, Calif

Colson JC (1968) On the education of archivists and librarians. Am Arch 31:167-174

Colson JC (1973) Archivists and education: modifying library school curricula. RQ 12:267-272

Connor RDW (1943) Adventures of an amateur archivist. Am Arch 6:1-18

Conway P (1988) Archival education and the need for full-time faculty. Am Arch 51:254-265. https://doi. org/10.17723/aarc.51.3.h83w32487q870239

Conway P, Banks B, Lenoil NZ, Suarez SJ (2011) The view from here: perspectives on educating about archives. Am Arch 74(306):1-32

Cook T (2000) "The Imperative of Challenging Absolutes" in graduate archival education programs: issues for educators and the profession. Am Arch 63:380-391. https://doi.org/10.17723/aarc.63.2. $27438310 \mathrm{j} 3390088$

Corbin J, Strauss A (1990) Grounded theory research: procedures, canons, and evaluative criteria. Qual Sociol 13:3-21. https://doi.org/10.1007/BF00988593

Couture C (1996) Today's students, tomorrow's archivists: present-day focus and development as determinants of archival science in the twenty-first century. Archivaria 42:95-104

Cox RJ (1986) Professionalism and archivists in the United States. Am Arch 49:229-247. https://doi.org/ 10.17723/aarc.49.3.p0vg1v6410254574

Cox RJ (1990a) A research agenda for archival education in the United States. American archival analysis: the recent development of the archival profession in the United States. Scarecrow Press, Metuchen, NJ, pp 113-163

Cox RJ (1990b) Archival education in the US: old concerns, but new future? American archival analysis: the recent development of the archival profession in the United States. Scarecrow Press, Metuchen, NJ, pp 98-112

Cox RJ (1993) The master of archival studies and american education standards: an argument for the continued development of graduate archival education in the United States. Archivaria 36:221-231

Cox RJ (1994) Dancing: archival education and student research. Proven J Soc Ga Arch 12:1-19

Cox RJ (2000a) The society of American archivists and graduate education: meeting at the crossroads. Am Arch 63:368-379. https://doi.org/10.17723/aarc.63.2.r64t27100718121r

Cox RJ (2000b) Employing records professionals in the information age. Inf Manag J 34:18

Cox RJ (2006) Are there really new directions and innovations in archival education? Arch Sci 6:247261. https://doi.org/10.1007/s10502-006-9032-4

Cox RJ (2009) Unpleasant things: teaching advocacy in archival education programs. InterActions UCLA $\mathrm{J}$ Educ Inf Stud 5

Cox RJ (2012) Where is archival science in the history of information science? A speculative framework. In: Carbo T, Hahn TB (eds) International perspectives on the history of information science and technology: proceedings of the ASIS\&T 2012 pre-conference on the history of ASIS\&T and information science and technology, ASIS\&T monograph series. Published for the American Society for Information Science and Technology by Information Today, Inc, Medford, New Jersey, pp 39-48

Cox RJ (2015) Graduate archival education in the United States; A personal reflection about its past and future. J Contemp Arch Stud 2

Cox RJ, Larsen RL (2008) iSchools and archival studies. Arch Sci 8:307-326. https://doi.org/10.1007/ s10502-009-9092-3

Cox RJ, Yakel E, Wallace D, Bastian JA, Marshall J (2001a) Educating archivists in library and information science schools. J Educ Libr Inf Sci 42:228-240. https://doi.org/10.2307/40324014

Cox RJ, Yakel E, Wallace D, Marshall J (2001b) Archival education in North American library and information science schools. Libr Q 71:141-194. https://doi.org/10.1086/603260

Craig BL (1996) Serving the truth: the importance of fostering archives research in education programmes, including a modest proposal/or partnerships with the workplace. Archivaria 42:105-117

Davis S (1989) Archival education: the next step. Midwest Arch 14:13-21 
Duranti L (1993) The archival body of knowledge: archival theory, method, and practice, and graduate and continuing education. J Educ Libr Inf Sci 34:8. https://doi.org/10.2307/40323707

Duranti L, Gilliland-Swetland A (1999) Archival doctoral education: an issue and challenge for the archival profession. Arch Outlook 4:23

Eastwood T (1988) Nurturing archival education in the university. Am Arch 51:228-252. https://doi.org/ 10.17723/aarc.51.3.qgk71605x660gm85

Eastwood T (2006) Building archival knowledge and skills in the digital age. Arch Sci 6:163-170. https://doi.org/10.1007/s10502-006-9026-2

Eastwood T (2017) A personal reflection on the development of archival education. EFI 33:75-88. https://doi.org/10.3233/EFI-170990

Ericson TL (1993) "Abolish the Recent": the progress of archival education. J Educ Libr Inf Sci 34:25. https://doi.org/10.2307/40323708

Evans F (1972) Educational needs for work in archival and manuscript depositories. Indian Arch 21:13-30

Evans F (1977) Postappointment archival training: a proposed solution for a basic problem. Am Arch 40:57-74. https://doi.org/10.17723/aarc.40.1.q8468168205266v5

Evans M (2020) The ongoing effort of creating an inclusive profession. Off the record. URL https:// offtherecord.archivists.org/2020/03/23/the-ongoing-effort-of-creating-an-inclusive-profession/. Accessed 23 Mar 2020

Evans MR (2021) WE are SAA. Am Arch 84:7-12. https://doi.org/10.17723/0360-9081-84.1.7

Francis MR (2015) 2013 archival program graduates and the entry-level job market. Am Arch 78:514-547. https://doi.org/10.17723/0360-9081.78.2.514

Franks PC (2012) Developing a blended learning model for an online degree program in library and information science. IFLA SET Bull 13:13-15

Franks PC (2016) Enterprise content management and digital preservation online education: a case study. In: Moffett S, Galbraith B (eds) Proceedings of the 17th European conference on knowledge management. Academic Conferences and Publishing International Ltd., Ulster, Northern Ireland, UK, pp 266-274

Franks PC, Oliver GC (2012) Experiential learning and international collaboration opportunities: virtual internships. Libr Rev 61:272-285. https://doi.org/10.1108/00242531211267572

Freeman ET (1991) Soap and education: archival training, public service and the profession-an essay. Midwest Arch 16:87-94

Fulton B, Botticelli P, Bradley J (2011) DigIn: a hands-on approach to a digital curation curriculum for professional development. J Educ Libr Inf Sci 52:95-109

Gabehart A (1992) Qualifications desired by employers for entry-level archivists in the United States. Am Arch 55:420-443. https://doi.org/10.17723/aarc.55.3.r1uh450u01243020

Galloway P (2011) Educating for digital archiving through studio pedagogy, sequential case studies, and reflective practice. Archivaria 72:169-196

Geary JW (1979) A fading relationship: library schools and preappointment archival education since 1973. J Educ Librariansh 20:25. https://doi.org/10.2307/40322861

Gilliland AJ (2011) Neutrality, social justice and the obligations of archival education and educators in the twenty-first century. Arch Sci 11:193-209. https://doi.org/10.1007/s10502-011-9147-0

Gilliland AJ (2014) Pluralizing archival education: a non-zero-sum proposition. In: Caldera MA, Neal KM (eds) Through the archival looking glass: a reader on diversity and inclusion. Society of American Archivists, Chicago, IL, pp 235-272

Gilliland AJ (2016) Building the scholarly base of a field: reflections on 8 years of the archival education and research initiative (AERI). Preserv Dig Technol Cult. https://doi.org/10.1515/ pdtc-2016-0004

Gilliland AJ, McKemmish S, White K, Lu Y, Lau A (2008) Pluralizing the archival paradigm: can archival education in pacific rim communities address the challenge? Am Arch 71:87-117. https://doi.org/10.17723/aarc.71.1.781w61g4r2kh3708

Gilliland-Swetland A (1998) Graduate archival education and the professional market: perspectives on data and data gathering. Archival Issues 23

Glaser BG, Strauss AL (2009) The discovery of grounded theory: strategies for qualitative research, 4th edn. Aldine, New Brunswick

Gorman GE, Clayton P (2005) Case studies in information organizations. In: Gorman GE, Clayton P (eds) Qualitative research for the information professional. Facet, London, England, pp 47-63 
Greene M (2010) MPLP: it's not just for processing anymore. Am Arch 73:175-203. https://doi.org/ 10.17723/aarc.73.1.m577353w31675348

Greene M, Meissner D (2005) More product, less process: revamping traditional archival processing. Am Arch 68:208-263

Gregory L, Guss S (2011) Digital curation education in practice: catching up with two former fellows. IJDC 6:176-194. https://doi.org/10.2218/ijdc.v6i2.195

Guidelines for a Graduate Program in Archival Studies [WWW Document] (2002). URL https://web. archive.org/web/20020806103846/http:/www.archivists.org/prof-education/ed_guidelines.asp\#_ ftn1

Harvey R, Bastian JA (2012) Out of the classroom and into the laboratory: teaching digital curation virtually and experientially. IFLA J 38:25-34. https://doi.org/10.1177/0340035211435072

Hedstrom M (1993) Teaching archivists about electronic records and automated techniques: a needs assessment. Am Arch 56:424-433. https://doi.org/10.17723/aarc.56.3.b568x1566m274061

Helmuth R (1981) Education for American archivists: a view from the trenches. Am Arch 44:295-303. https://doi.org/10.17723/aarc.44.4.x66537344mh24677

Hodder I (2000) The interpretation of documents and material culture. In: Lincoln NK (ed) Handbook of qualitative research. SAGE, Thousand Oaks, pp 703-715

Israel RH, Eyre JR (2017) The 2017 WArS/SAA salary survey: initial results and analysis

Jones H (1968) Archival training in American universities, 1938-68. Am Arch 31:135-154. https://doi. org/10.17723/aarc.31.2.0g14n817068gv665

Joyce W (1988) Archival education: two fables. Am Arch 51:16-22. https://doi.org/10.17723/aarc.51.1-2. p4j85330k171023g

Kahn H (1971) Some comments on the archival vocation. Am Arch 34:3-12

Kahn H, Evans F, Hinding A (1975) Documenting American cultures through three generations: change and continuity. Am Arch 38:147-151. https://doi.org/10.17723/aarc.38.2.aq740p1177j61441

Kelly K, Marlino M, Mayernik MS, Allard S, Tenopir C, Palmer CL, Varvel VE Jr (2013) Model development for scientific data curation education. IJDC 8:255-264. https://doi.org/10.2218/ijdc.v8i1. 258

Kesner R (1993) Teaching archivists about information technology concepts: a needs assessment. Am Arch 56:434-443

Kim Y, Addom BK, Stanton JM (2011) Education for eScience professionals: integrating data curation and cyberinfrastructure. IJDC 6:125-138. https://doi.org/10.2218/ijdc.v6i1.177

Kovan A (1988) Helping friends: archives training for public historians. Am Arch 51:312-318

Leazer G (2016) iSchools, legitimacy, and the contribution of archival studies to the iSchool movement. In: IConference 2016 proceedings. Presented at the iConference 2016: partnership with society, iSchools, Philadelphia, USA. https://doi.org/10.9776/16263

Lee CA (2009) Curation junction, what's your function? Defining what it means to do digital curation in order to teach it. In: Proceedings of the 2009 annual conference of the association for library and information science education (ALISE)

LeFurgy W (1981) The practicum: a repository view. Am Arch 44:153-155

Lyon L, Brenner A (2015) Bridging the data talent gap: positioning the iSchool as an agent for change. IJDC 10:111-122. https://doi.org/10.2218/ijdc.v10i1.349

Maher W (1988) Contexts for understanding professional certification: opening pandora's box? Am Arch 51:408-427. https://doi.org/10.17723/aarc.51.4.h17366pq25501482

Manoff M (2004) Theories of the archive from across the disciplines. Portal Libr Acad 4:9-25. https:// doi.org/10.1353/pla.2004.0015

Martin R (1994) The development of professional education for librarians and archivists in the United States: a comparative essay. Am Arch 57:544-558. https://doi.org/10.17723/aarc.57.3.116720kn81 j25108

Mason P (1972) The society of American archivists in the seventies report of the committee for the 1970's. Am Arch 35:193-217. https://doi.org/10.17723/aarc.35.2.9w138685g66602v0

Mayernik MS, Thompson CA, Williams V, Allard S, Palmer CL, Tenopir C (2015) Enriching education with exemplars in practice: iterative development of data curation internships. IJDC 10:123-134. https://doi.org/10.2218/ijdc.v10i1.350

McCrank L (1979) Prospects for integrating historical and information studies in archival education. Am Arch 42:443-455. https://doi.org/10.17723/aarc.42.4.24634713227172j0 
McCrank L (1980) Present developments in archival education: the future care of the past. In: Fyfe J, Collier C (eds) Symposium on archival education. University of Western Ontario, London, Ontario, School of Library and Information Science, pp 11-41

McCrank L (1985) Public historians in the information professions: problems in education and credentials. Public Hist 7:7-22. https://doi.org/10.2307/3377123

McGovern NY (2018) Archives, history, and technology: prologue and possibilities for SAA and the archival community. Am Arch 81:9-22. https://doi.org/10.17723/0360-9081-81.1.9

Meissner D (2017) Bare necessities. Am Arch 80:6-18. https://doi.org/10.17723/0360-9081.80.1.6

Meissner D, Greene MA (2010) More application while less appreciation: the adopters and antagonists of MPLP. J Arch Organ 8:174-226. https://doi.org/10.1080/15332748.2010.554069

Miller F (2000) The SAA as Sisyphus: education since the 1960s. Am Arch 63:224-236. https://doi.org/ 10.17723/aarc.63.2.kh857t69xm658527

Moen WE, Kim J, Warga EJ, Wakefield JS, Halbert M (2012) iCAMP: building digital information curation curriculum. In: Proceedings of the 2012 IConference on-IConference ' 12 . Presented at the the 2012 iConference, ACM Press, Toronto, Ontario, Canada, pp 648-650. https://doi.org/10.1145/ 2132176.2132324

Nesmith T (1996) 'Professional education in the most expansive sense': what will the archivist need to know in the twenty-first century? Archivaria 42:89-94

Newsome A (1939) The archivist in American scholarship. Am Arch 2:217-224. https://doi.org/10. 17723/aarc.2.4.6706152457635438

Palmer CL, Heidorn BP, Wright D, Cragin MH (2008) Graduate curriculum for biological information specialists: a key to integration of scale in biology. IJDC 2:31-40. https://doi.org/10.2218/ijdc. v2i 2.27

Peace N, Chudacoff N (1979) Archivists and librarians: A common mission, a common education. Am Arch 42:456-462. https://doi.org/10.17723/aarc.42.4.t12r201v6g5g1166

Peterson T, Quinn P, Taylor H (1977) Professional archival training. Am Arch 40:315-320. https://doi. org/10.17723/aarc.40.3.54316w0666x5u67t

Pickard AJ (2013a) Case studies. In: Pickard AJ (ed) Research methods in information. Facet, London, pp 101-111

Pickard AJ (2013b) Interviews. In: Pickard AJ (ed) Research methods in information. Facet, London, pp 195-207

Pickard AJ (2013c) Sampling. In: Pickard AJ (ed) Research methods in information. Facet, London, pp 59-69

Pluralizing the Archival Curriculum Group (2011) Educating for the archival multiverse: the archival education and research institute (AERI), pluralizing the archival curriculum group (PACG). Am Arch 74:69-101. https://doi.org/10.17723/aarc.74.1.hv33964712745684

Poole AH (2014) The strange career of Jim Crow archives: race, space, and history in the mid-twentieth-century American south. Am Arch 77:23-63. https://doi.org/10.17723/aarc.77.1.g621m3701g 821442

Poole AH (2017a) Pinkett's charges: recruiting, retaining, and mentoring archivists of color in the twentyfirst century. Am Arch 80:103-134. https://doi.org/10.17723/0360-9081.80.1.103

Poole AH (2017b) Harold T. Pinkett and the lonely crusade of African American archivists in the twentieth century. Am Arch 80:296-335. https://doi.org/10.17723/0360-9081-80.2.296

Poole AH (2018) "Be Damned Pushy at Times": the committee on the status of women and feminism in the archival profession, 1972-1998. Am Arch 81:394-437. https://doi.org/10.17723/0360-908181.2.394

Posner E (1941) European experiences in training archivists. Am Arch 4:26-37. https://doi.org/10.17723/ aarc.4.1.g586337546433651

Posner E (1957) What, then, is the American Archivist, this new man? Am Arch 20:3-11. https://doi.org/ 10.17723/aarc.20.1.10h7186h04u21887

Posner E (1967) Archival training in the United States. Archives and the public interest. Public Affairs Press, Washington, D.C., pp 58-77

Prior L (2003) Using documents in social research. SAGE Publications Ltd, London, UK. https://doi.org/ $10.4135 / 9780857020222$

Renear A, Teffeau L, Hswe P, Dolan M, Palmer CL, Cragin MH, Unsworth JM (2009) Extending an LIS Data curriculum to include humanities data. In: Tibbo HR, Lee CA, Clemens R (eds) Digital curation: practices, promise, and prospects. Presented at the DigCCurr 2009. School of Information and Library Science, Chapel Hill, NC, pp 191-193 
Roe KD (2016) Why archives? Am Arch 79:6-13. https://doi.org/10.17723/0360-9081.79.1.6

Ross R (1981) Ernst posner: the bridge between the old world and the new. Am Arch 44:304-312. https:// doi.org/10.17723/aarc.44.4.r702n30500165p83

Rubin HJ, Rubin I (2005) Qualitative interviewing: the art of hearing data, 2nd edn. Sage Publications, Thousand Oaks, Calif

Saldaña J (2013) The coding manual for qualitative researchers, 2nd edn. SAGE, Los Angeles

Schaeffer R (1994) From craft to profession: the evolution of archival education and theory in North America. Archivaria 37:21-34

Schellenberg T (1968) Archival training in library schools. Am Arch 31:155-165. https://doi.org/10. 17723/aarc.31.2.g2k6132m5332737k

Schwandt TA, Gates EF (2018) Case study methodology. In: Denzin NK, Lincoln YS (eds) The SAGE handbook of qualitative research. SAGE, Los Angeles, CA, pp 341-358

Shenton AK (2013) Analysis of existing, externally created material. In: Pickard AJ (ed) Research methods in information. Facet, London, pp 251-261

Smith W (1974) Broad Horizons: opportunities for archivists. The American archivist 37. Society of American archivists guidelines for graduate archival education programs, 1988. Am Arch 51:380-389

Smith VR (1994) Pedagogy and professionalism: an evaluation of trends and choices confronting educators in the archival community. Public Hist 16:23-43. https://doi.org/10.2307/3378498

Society of American Archivists (1988) Society of American archivists guidelines for graduate archival education programs. Am Arch 51:380-389

Soyka HA, Wilczek E (2020) Ten years of Archival Education and Research Institutes: a snapshot of scholarship. Arch Sci. https://doi.org/10.1007/s10502-020-09331-2

Star SL (1988) Introduction: the sociology of science and technology. Soc Probl 35:197-205

Star SL (1995) Ecologies of knowledge: work and politics in science and technology. State University of New York Press, Albany, NY

Stielow FJ (1985) Continuing education and information management: or, the monk's dilemma. Proven J Soc Ga Arch 3:13-22

Stielow FJ (1990) The practicum and the changing face of archival education. Proven J Soc Ga Arch 8:1-12

Stielow FJ (1993) The impact of information technology on archival theory: a discourse on an automation pedagogy. J Educ Libr Inf Sci 34:48-65

Tansey E (2015) The landscape of archival employment: a study of professional archivist job advertisements, 2006-2014. Archival Practice 2

Tibbo HR (1997) A vision of archival education at the Millennium. J Educ Libr Inf Sci 38:221-225. https://doi.org/10.2307/40324207

Tibbo HR (2006) So much to learn, so little time to learn it: North American archival education programs in the information age and the role for certificate programs. Arch Sci 6:231-245. https://doi.org/10. 1007/s10502-006-9031-5

Tibbo HR (2012) On the occasion of SAA's diamond jubilee: a profession coming of age in the digital Era (with an introduction by Jane Kenamore). Am Arch 75:16-34. https://doi.org/10.17723/aarc. 75.1.a054u0t82478x41v

Tibbo HR (2015) Digital curation education and training: from digitization to graduate curricula to MOOCs. IJDC 10:144-153. https://doi.org/10.2218/ijdc.v10i1.352

Trever K (1948) The organization and status of archival training in the United States. Am Arch 11:154163. https://doi.org/10.17723/aarc.11.2.4178j71382770886

Van House NA (2005) Science and technology studies and information studies. Ann Rev Info Sci Tech 38:1-86. https://doi.org/10.1002/aris.1440380102

Walters T (1991) Possible educations for archivists: integrating graduate archival education with public history education programs. Am Arch 54:484-492. https://doi.org/10.17723/aarc.54.4.rj20243h40 463587

Warner R (1972) Archival training in the United States and Canada. Am Arch 35:347-358. https://doi. org/10.17723/aarc.35.3-4.125k6746779094q7

Weber LB (1988) Educating archivists for automation. Libr Trends 36:501-518

Weiss RS (1995) Learning from strangers: the art and method of qualitative interview studies. Free Press, New York

Welch E (1975) The necessity of education. Ga Arch 3:103-106 
White KL (2009) Meztizaje and remembering in Afro-Mexican communities of the Costa Chica: implications for archival education in Mexico. Arch Sci 9:43-55. https://doi.org/10.1007/ s10502-009-9102-5

Wildemuth B (2009) Existing documents and artifacts as data. In: Wildemuth B (ed) Applications of social research methods to questions in information and library science. Libraries Unlimited, Westport, CT, pp 158-165

Wosh PJ (1982) Creating a semi-professional profession. Ga Arch 10:1-13

Yakel E (2004) Educating archival professionals in the twenty-first century. OCLC Syst Serv Int Dig Libr Perspect 20:152-154. https://doi.org/10.1108/10650750410564628

Yakel E, Conway P, Hedstrom M, Wallace DA (2011) Digital curation for digital natives. J Educ Libr Inf Sci 52:23-31

Yin R (2009) Case study research: design and methods. SAGE, Los Angeles

Zanish-Belcher T (2019) Keeping evidence and memory archives storytelling in the twenty-first century. Am Arch 82:9-23. https://doi.org/10.17723/0360-9081-82.1.9

Zhang J (2015) Archival scholarship in the nation's capital: Ernst Posner. In: Cox RJ, Mattern E, Langmead A (eds) Archival research and education: selected papers from the 2014 AERI conference. Litwin Books, Sacramento, pp 135-155

Publisher's Note Springer Nature remains neutral with regard to jurisdictional claims in published maps and institutional affiliations.

Alex H. Poole Associate Professor at Drexel University's College of Computing and Informatics, Alex H. Poole studies archives and records management, diversity, equity, and inclusion, digital curation, and digital humanities. Poole received the Jesse H. Shera Award for Distinguished Published Research from the American Library Association in 2019, the Bob Williams History Fund Research Paper Award from the Association for Information Science and Technology in both 2018 and 2017, the Arline Custer Memorial Award for Best Article from the Mid-Atlantic Regional Archives Conference (MARAC) in 2018, and the Theodore Calvin Pease Award from the Society of American Archivists in 2013. He is the Principal Investigator for the IMLS-funded "Exploring New Frontiers in Twenty-First Century Archival Education" (2020-2022).

Ashley Todd-Diaz, Ph.D., is Assistant University Librarian for Special Collections and University Archives at Towson University. Her research interests are libraries and archives as organizations, graduate archival education, and archival literacy. She teaches as an adjunct in Drexel University's College of Computing and Informatics and Emporia State University's School of Library and Information Management. 